\title{
The Emission of Carbon Monoxide and Nitrogen Oxides from Boilers Supplied by a Pellet under the Influence of Changes in the Air-Fuel Equivalence Ratio
}

\author{
Bartosz Ciupek ${ }^{1 *}$, Wojciech Judt ${ }^{1}$, Rafał Urbaniak' ${ }^{1}$, Robert Kłosowiak ${ }^{1}$ \\ 1 Poznan University of Technology, Faculty of Transport Engineering, Chair of Thermal Engineering, \\ ul. Piotrowo 3, 60-965 Poznań, Poland \\ * Corresponding author's e-mail: bartosz.ciupek@put.poznan.pl
}

\begin{abstract}
The aim of the experimental research was to determine the impact of changes in the air-fuel equivalence ratio during the combustion of wood pellet in the boiler on the $\mathrm{CO}$ and $\mathrm{NO}_{\mathrm{X}}$ emissions. In order to realize the tests, $10 \mathrm{~kW}$ wood pellet boiler equipped with a dedicated wood pellet burner was employed. On the basis of the research, the relationship between the level of harmful substances emitted under the influence of changes in the air-fuel equivalence ratio was presented. The obtained results and conclusions based on them can be used to optimize the design of heating devices fed by wood pellets.
\end{abstract}

Keywords: heating boiler, wood pellet, air-fuel equivalence ratio, $\mathrm{CO}, \mathrm{NO}_{\mathrm{x}}$

\section{INTRODUCTION}

The studies on the emission of harmful substances from solid fuel boilers have been conducted for several years [Creutzig et al. 2015; Obernberger et al. 2004]. The majority of the works show an identical approach of scientists to the research on boilers, describing the boiler as a technical object interacting between man and the environment [Rashid et al. 2014; Sippula et al. 2008]. Previous studies showed a significant impact of technical parameters of fuels on the variability of mass concentrations of $\mathrm{CO}$ and $\mathrm{NO}_{\mathrm{X}}$ emitted from their combustion. Moreover, the studies on co-combustion of carbon fuels with wood and non-wood biomass show convergent courses of emitted harmful substances, which allows the application of analogous research methods [Shao et al. 2012; Sommersacher et al. 2012]. In the publication [Ciupek et al. 2019], with reference to thermodynamics, the solid fuel boiler was considered as a closed heterogeneous system with a strong impact on the external environment, conditioned by the physicochemical parameters of the burnt fuel. The parameters of the burnt fuel significantly influenced the change of the boiler operation parameters through the changeable physical and chemical properties of the fuel. This approach involved mapping the scale of the problem in terms of the emissions of harmful substances, without reference to the chemical aspects of the combustion process. In the publications [Caseiro et al. 2009; Verma et al. 2011], the subject of harmful substances emission from the boiler equipment not subject to environmental register was discussed. They show that many district heating plants located close to each other have a significant contribution to the emission of harmful substances in a given area. The concentrations of harmful substances in flue gases emitted by boilers calculated by the researchers exceeded the assumptions of standards and directives many times over.

The scale of the problem related to the emission of harmful substances in Poland caused by the use of heating boilers for solid fuels shows the necessity to introduce modern technologies allowing to significantly reduce the amount of harmful substances emitted to the environment. 
The issues related to the influence of the chemical composition of combusted fuels on the emission of harmful substances from boilers are discussed in the publications [Joseph et al. 2018; Staiger et al. 2005; Stubenberger et al. 2008]. The publications [Barranco et al. 2007; Carrillo et al. 2014; Runge et al. 2014] show that the level of harmful emissions is directly related to the technical parameters of the appliance and the fuel being combusted.

Wood pellets with technical parameters described as: combustion heat $\left(\mathrm{H}_{\mathrm{s}}\right)$, moisture content $\left(\mathrm{W}_{\mathrm{t}}\right)$, ash content $\left(\mathrm{A}^{\mathrm{a}}\right)$ and volatile components $\left(\mathrm{V}^{\text {daf }}\right)$ were selected for the study. The heat and emission work of the boiler during operation at its nominal output for three different excess air coefficients was analysed. The results obtained were presented in summary tables and on the figures presenting mass distributions of $\mathrm{CO}$ and $\mathrm{NO}_{\mathrm{x}}$ emitted in relation to the air-fuel equivalence ratio $(\lambda)$.

\section{METHODS}

The test facility used in the tests was a pellet boiler with a nominal output of $10 \mathrm{~kW}$ equipped with an automatic pellet burner, meeting the technical requirements for boilers built in accordance with EU Directive 2015/1189. The technical parameters of the fuel are shown in Table 1.

During the tests, the thermal power of the boiler oscillated around the rated power of the device. The amplitude of thermal power varied within $\pm 1 \mathrm{~kW}$ from the rated power. The BCA-01 flue gas analyser was responsible for the measurement of the $\mathrm{O}_{2}$ content in the exhaust gases. Its measurement range ranged from $0 \%$ to $+25 \%$ of oxygen volume, and the measurement error was $\pm 0.8 \%$. The TESTO $350 \mathrm{XL}$ exhaust gas analyser was responsible for the measurement of mass concentrations of $\mathrm{CO}$ and $\mathrm{NO}_{\mathrm{x}}$. The analyzer was equipped with photochemical measurement targets. The analysis time was set as one sample per second. The accuracy of $\mathrm{CO}$ measurement was $\pm 5 \%$ and for $\mathrm{NO}_{\mathrm{X}} \pm 5 \%$. Thermocouples type

Table 1. Technical parameters of fuel used in tests

\begin{tabular}{|c|c|c|c|c|}
\hline Fuel & $\begin{array}{c}\text { Combustion } \\
\text { heat, MJ/kg }\end{array}$ & $\begin{array}{c}\text { Moisture, } \\
\%\end{array}$ & $\begin{array}{c}\text { Ash, } \\
\%\end{array}$ & $\begin{array}{c}\text { Volatile } \\
\text { components, } \\
\%\end{array}$ \\
\hline $\begin{array}{c}\text { Wood } \\
\text { pellet }\end{array}$ & 18.20 & 10.10 & 0.70 & 67.60 \\
\hline
\end{tabular}

$\mathrm{K}$ (NiCr-Ni) with measuring range from $-200^{\circ} \mathrm{C}$ to $+1370^{\circ} \mathrm{C}$ and measuring error of $\pm 0.4^{\circ} \mathrm{C}$ were used for temperature measurement. The heat loss in the heating system amounted to approx. $-2.5 \%$. The system of plate heat exchangers was responsible for the reception of the generated heat.

The measurements were carried out for three test cycles. The tests were carried out for three different air-fuel equivalence ratios: $\lambda_{1}=2.30$, $\lambda_{2}=1.90$ and $\lambda_{3}=1.50$. In the first cycle, the emission level of substances harmful to the automatically fired boiler was tested at $\lambda_{1}=2.30$. In the next cycle, the tests for emission of harmful substances at $\lambda_{2}=1.90$ were carried out. In the last cycle, the same tests were carried out as for the previous ones, but $\lambda_{3}=1.50$.

Registration of the measurement data was based on a test stand equipped with a PC and a system of measurement cards type ADAM- 4118 . The computer setup was responsible for collecting the measurement data from the exhaust gas analyzers, while the measurement cards and a dedicated registration program were responsible for the temperature measurement. The mass concentrations of $\mathrm{CO}$ and $\mathrm{NO}_{\mathrm{x}}$ were converted to $\mathrm{mg} / \mathrm{m}^{3}$ for $10 \% \mathrm{O}_{2}$ in the exhaust gas. The conversion resulted from the emission assumptions made for boilers in accordance with the PN-EN 303-5:2012 standard. The results of the flue gas temperature were averaged by the measurement carried out by five thermocouples. In order to determine the fuel consumption of the boiler, a weighing station was used, measuring the mass of fuel charge before and after the tests. On the basis of the fuel consumed during the tests, the mass flow of the fuel burnt was determined. In addition, the air-fuel equivalence ratios $(\lambda)$ and boiler heat efficiency $(\eta)$ were calculated on the basis of the data recorded.

\section{RESULTS}

The results of tests for the first cycle are presented in Table 2. The obtained emission distributions of harmful substances are presented in Figs. 1 and 2. The boiler operated in the range of air-fuel equivalence ratio from 1.75 to 2.85 . The range of flue gas temperature ranged from $83^{\circ} \mathrm{C}$ to $104^{\circ} \mathrm{C}$. The efficiency of the combustion process ranged from $93 \%$ to $97 \%$.

The results for the second cycle of tests are presented in Table 3. The obtained distributions 
Table 2. Results for the first cycle test

\begin{tabular}{|c|c|c|c|c|c|c|}
\hline Specification & $\mathrm{O}_{2}, \%$ & $\mathrm{CO}, \mathrm{mg} / \mathrm{m}^{3}$ & $\mathrm{NO}_{\mathrm{x}}, \mathrm{mg} / \mathrm{m}^{3}$ & $\mathrm{~T}_{\mathrm{sP}}{ }^{\circ} \mathrm{C}$ & $\lambda$ & $\eta, \%$ \\
\hline average & 11.85 & 133.93 & 159.22 & 93.00 & 2.32 & 95.18 \\
\hline minimum & 9.00 & 8.00 & 87.00 & 83.00 & 1.75 & 93.20 \\
\hline maximum & 13.60 & 521.00 & 199.00 & 104.00 & 2.85 & 96.60 \\
\hline
\end{tabular}

of harmful substances emission are presented in Figs. 3 and 4. On the basis of the results it was observed that the reduction of air-fuel equivalence ratio caused an increase in the amount of $\mathrm{CO}$ emitted in relation to the first cycle of tests by $112 \mathrm{mg} / \mathrm{m}^{3}$. The $\mathrm{NO}_{\mathrm{x}}$ emissions decreased by about $4 \mathrm{mg} / \mathrm{m}^{3}$. The boiler operated in the air-fuel equivalence ratio from 1.58 to 2.37 . The flue gas temperature range ranged from $99^{\circ} \mathrm{C}$ to $138^{\circ} \mathrm{C}$. The efficiency of the combustion process ranged from $89 \%$ to $94 \%$.

The results for the third test cycle are presented in Table 4. The obtained emission distributions of harmful substances are presented in Fig. 5 and 6. On the basis of the results, it was observed that the reduction of air-fuel equivalence ratio caused an increase in the amount of $\mathrm{CO}$ emitted in relation to the first test cycle by $184 \mathrm{mg} / \mathrm{m}^{3}$ and in relation to the second test cycle by $72 \mathrm{mg} / \mathrm{m}^{3}$. The $\mathrm{NO}_{\mathrm{x}}$ emissions from the first test cycle decreased by approximately $8 \mathrm{mg} / \mathrm{m}^{3}$ and from the second test cycle - by $4 \mathrm{mg} / \mathrm{m}^{3}$. The boiler operated in the air-fuel equivalence ratio range from 1.36 to 1.86 . The flue gas temperature ranged from $139^{\circ} \mathrm{C}$ to $150^{\circ} \mathrm{C}$. The efficiency of the combustion process ranged from $88 \%$ to $91 \%$.

\section{CONCLUSIONS}

The studies on the influence of air-fuel equivalence ratio $(\lambda)$, change on $\mathrm{CO}$ and $\mathrm{NO}_{\mathrm{X}}$ emission from a pellet boiler were carried out. On the basis of the results obtained, it can be seen that the decrease in the amount of air supplied to the combustion process affects the increase in $\mathrm{CO}$ emissions. In the case of $\mathrm{NO}_{\mathrm{x}}$, a reduction in emissions was observed. Decreasing the air-fuel equivalence ratio $(\lambda)$ caused an increase in the temperature of exhaust gases. From the thermodynamic point of view, the change in the temperature of flue gases caused a decrease in the intensification of heat exchange between flue gases and the heating factor, which resulted in a 5\% decrease in the efficiency of the combustion process. The results obtained from the research give grounds for further research on the influence of the air-fuel equivalence ratio $(\lambda)$, as well as the changes on the chemical composition of exhaust gases. In the case of classic boiler designs, the reduction of the incoming air flow rate has a positive effect on the reduction of $\mathrm{NO}_{\mathrm{x}}$ emissions; however, it results in a multiple increase of $\mathrm{CO}$.

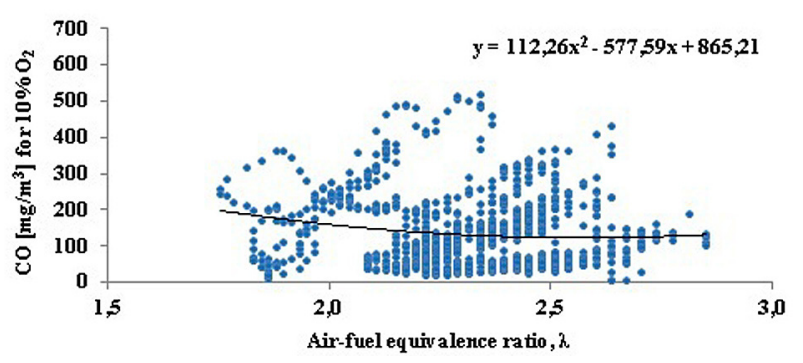

Fig. 1. The course of $\mathrm{CO}$ emissions for first cycle of research

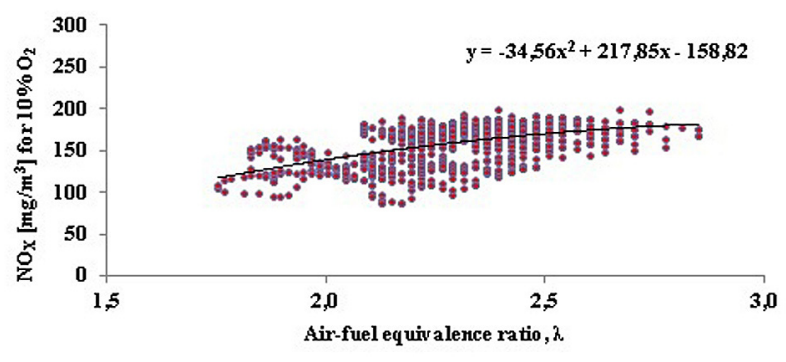

Fig. 2. The course of $\mathrm{NO}_{\mathrm{X}}$ emissions for first cycle of research 
Table 3. Results for the second cycle test

\begin{tabular}{|c|c|c|c|c|c|c|}
\hline Specification & $\mathrm{O}_{2}, \%$ & $\mathrm{CO}, \mathrm{mg} / \mathrm{m}^{3}$ & $\mathrm{NO}_{x}, \mathrm{mg} / \mathrm{m}^{3}$ & $\mathrm{~T}_{\mathrm{SP}},{ }^{\circ} \mathrm{C}$ & $\lambda$ & $\eta, \%$ \\
\hline average & 9.68 & 245.48 & 155.89 & 117.00 & 1.87 & 92.40 \\
\hline minimum & 7.70 & 166.00 & 102.00 & 99.00 & 1.58 & 89.50 \\
\hline maximum & 12.10 & 480.00 & 182.00 & 138.00 & 2.37 & 94.50 \\
\hline
\end{tabular}

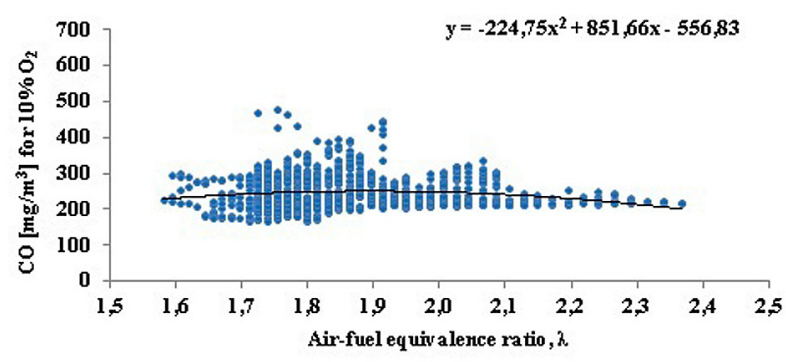

Fig. 3. The course of $\mathrm{CO}$ emissions for second cycle of research

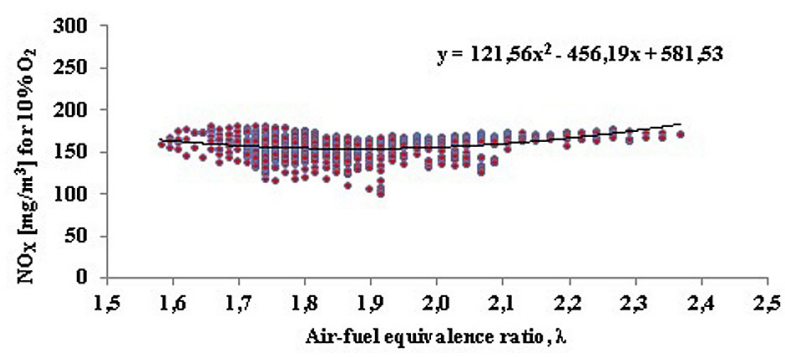

Fig. 4. The course of $\mathrm{NO}_{\mathrm{x}}$ emissions for second cycle of research

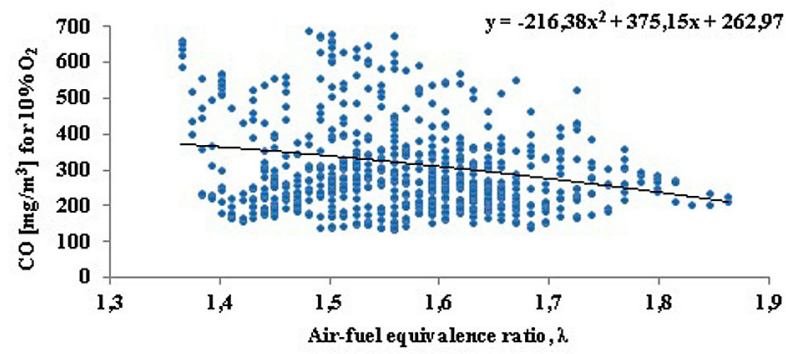

Fig. 5. The course of $\mathrm{CO}$ emissions for third cycle of research

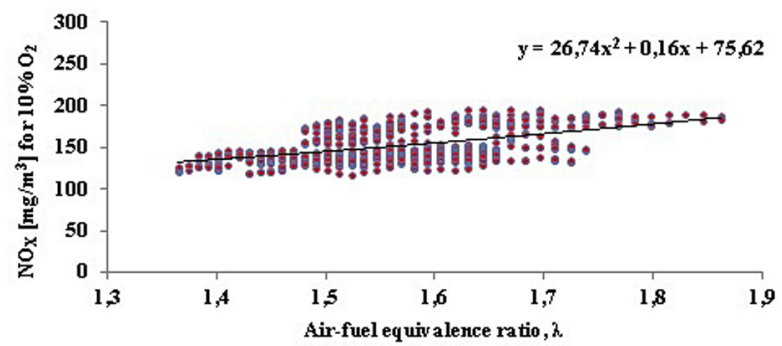

Fig. 6. The course of $\mathrm{NO}_{\mathrm{X}}$ emissions for third cycle of research 
Table 4. Results for the third cycle test

\begin{tabular}{|c|c|c|c|c|c|c|}
\hline Specification & $\mathrm{O}_{2}, \%$ & $\mathrm{CO}, \mathrm{mg} / \mathrm{m}^{3}$ & $\mathrm{NO}_{x}, \mathrm{mg} / \mathrm{m}^{3}$ & $\mathrm{~T}_{\mathrm{SP}}{ }^{\circ} \mathrm{C}$ & $\lambda$ & $\eta, \%$ \\
\hline average & 7.53 & 317.40 & 151.77 & 145.00 & 1.57 & 89.25 \\
\hline minimum & 5.60 & 134.00 & 117.00 & 139.00 & 1.36 & 88.00 \\
\hline maximum & 9.70 & 895.00 & 196.00 & 150.00 & 1.86 & 90.60 \\
\hline
\end{tabular}

\section{Acknowledgments}

The work was carried out within the framework of a scientific project no. POIR.04.01.04-00-0135/16 „Niskoemisyjny kocioł grzewczy na paliwo stałe $\mathrm{z}$ możliwością wykorzystania energii odpadowej”, financed by NCBR - Poland.

\section{REFERENCES}

1. Barranco R., Gong M., Thompson A., Cloke M., Hanson S., Gibb W., Lester E. 2007. The impact of fly ash resistivity and carbon content on electrostatic precipitator performance. Fuel, 86(16), 2521-2527.

2. Carrillo M.A., Staggenborg S.A., Pineda J.A. 2014. Washing sorghum biomass with water to improve its quality for combustion. Fuel 116, 427-431.

3. Caseiro, Bauer H., Schmidl C., Pio C.A., Puxbaum H. 2009. Wood burning impact on PM10 in three Austrian regions. Atmos. Environ., 43(13), 2186-2195.

4. Ciupek B., Janeba-Bartoszewicz E. Urbaniak R. 2019. Wpływ rozdrobnienia i zwiększonej wilgotności paliw węglowych na skład chemiczny spalin (in Polish). Przem. Chem., 98(8), 1000-1002.

5. Creutzig F., Ravindranath N.H., Berndes G., Bolwig S., Bright R., Cherubini F., Chum H., Corbera E., Delucchi M., Faaij A. 2015. Bioenergy and climate change mitigation: An assessment. GCB Bioenergy, 7, 916-944.

6. Joseph B., Hensgen F., Bühle L., Wachendorf M. 2018. Solid Fuel Production from Semi-Natural Grassland Biomass - Results from a CommercialScale IFBB Plant. Energies, 11(11), 3011.
7. Obernberger I., Thek G. 2004. Physical characterisation and chemical composition of densified biomass fuels withregard to their combustion behaviour. Biomass Bioenergy, 27, 653-669.

8. Rashid M., Syahirah M.M., NorRuwaida J., Huda N. 2014. Characteristics of Particulate Emission from a Biomass Fired Boiler. Agriculture and Agricultural Science Procedia, 2, 265-271.

9. Runge T., Wipperfurth P., Zhang C. 2014. Improving biomass combustion quality using a liquid hot water treatment [J]. Biofuels, 4(1), 73-83.

10. Shao Y., Wang J., Preto F., Zhu J., Xu C. 2012. Ash Deposition in Biomass Combustion or Co-Firing for Power/Heat Generation. Energies, 5, 5171-5189.

11. Sippula, Lind T., Jokiniemi J. 2008. Effects of chlorine and sulphur on particle formation in wood combustion performed in a laboratory scale reactor. Fuel, 87(12), 2425-2436.

12. Sommersacher P., Brunner T., Obernberger I. 2012. Fuel Indexes: A Novel Method for the Evaluation of Relevant Combustion Properties of New Biomass Fuels. Energy Fuels, 26, 380-390.

13. Staiger B., Unterberger S., Berger R., Hein K.R.G. 2005. Development of an air staging technology to reduce $\mathrm{NO}_{\mathrm{X}}$ emissions in grate fired boilers. Energy, 30(8), 1429-1438.

14. Stubenberger G., Scharler R., Zahirovic S., Obernberger I. 2008. Experimental investigation of nitrogen species release from different solid biomass fuels as a basic for release models. Fuel, 87(6), 793-806.

15. Verma V.K., Bram S., Gauthier G., De Ruyck J. 2011. Performance of a domestic pellet boiler as a function of operetional loads. Part 2. Biomass Bioenergy, 35(1), 272-279. 